\title{
41. DATA REPORT: OLIGOCENE AND MIOCENE SILICOFLAGELLATES FROM THE NORTHERN EMPEROR SEAMOUNT CHAIN, SITE $883^{1}$
}

\author{
David Bukry²
}

\begin{abstract}
Changes in silicoflagellate abundances at Detroit Seamount identify four new floras. Naviculopsis lata var. obliqua is abundant in the lower Miocene and it is possibly an endemic species in the North Pacific Ocean.
\end{abstract}

\section{INTRODUCTION}

Late Oligocene and early Miocene silicoflagellates are common to abundant and moderately well preserved in Ocean Drilling Program (ODP) Cores 145-883B-66X through 68X from Detroit Seamount at the northern end of the Emperor Seamount Chain (Fig. 1). Because this cored interval is near the Paleogene/Neogene boundary, systematic species counts $(n=50-300)$ were made for 29 samples from throughout the $23-\mathrm{m}$ interval (Table 1). The 31 taxa in six genera are assigned to the two zonal units that have been used to identify the Oligocene/Miocene boundary by silicoflagellates: Naviculopsis biapiculata Zone and $N$. lata Zone (Bukry, 1981). Prior reports on North Pacific Oligocene/Miocene boundary silicoflagellates have been limited to Japan (Sawamura and Nakajima, 1980) or Deep Sea Drilling Project (DSDP) sites (Bukry 1982, 1985).

Most of the Hole 883B samples studied were prepared for diatom studies (Barron and Gladenkov, this volume). Some were prepared as silicoflagellate acid residues (Bukry, 1983) for light-microscope study. Counting techniques followed those previously described in DSDP reports and the totals are presented as percentages (Bukry, 1985). Although fragmentation of specimens is evident in all three cores, there are no signs of dissolution.

\section{SILICOFLAGELLATE OCCURRENCES}

The succession of silicoflagellate species (Table 1) and genera (Table 2) at Hole 883B is characterized by two major changes in Core $67 \mathrm{X}$ and by a minor change in Core $66 \mathrm{X}$. The oldest flora, Flora $\mathrm{A}$ in Core $68 \mathrm{X}$ and lower Core $67 \mathrm{X}$, is distinguished from overlying Flora $\mathrm{B}$ by changes in several generic abundance patterns that coincide in Section 67X-4 (Table 2).

\begin{tabular}{|c|c|c|}
\hline & $\begin{array}{c}\text { Flora A } \\
(\%)\end{array}$ & $\begin{array}{c}\text { Flora B } \\
(\%)\end{array}$ \\
\hline Bachmannocena & $<9$ & $14-23$ \\
\hline Corbisema & $|-1|$ & 0 \\
\hline Dictyocha & $3-49$ & $<3$ \\
\hline Distephanus (quad.) & $19-52$ & $48-65$ \\
\hline Naviculopsis & $9-22$ & $<4$ \\
\hline
\end{tabular}

'Rea, D.K., Basov, I.A., Scholl, D.W., and Allan, J.F. (Eds.), 1995. Proc. ODP, Sci. Results, 145: College Station, TX (Ocean Drilling Program).

${ }^{2}$ Scripps Institution of Oceanography, Geological Research Division, and U.S. Geological Survey (MS-915), Paleontology and Stratigraphy Branch, 345 Middlefield Road, Menlo Park, CA 94025, U.S.A.
Because the core log does not show any prominent physical break, the A/B floral change could be a rapid regional current shift with essentially no time missing in the sediment record. But the floral change above Flora B is more abrupt and suggests an important break in the sediment record. The contrast between Flora B and Flora C is shown by the following changes:

\begin{tabular}{|c|c|c|}
\hline & $\begin{array}{c}\text { Flora B } \\
(\%)\end{array}$ & $\begin{array}{c}\text { Flora C } \\
(\%)\end{array}$ \\
\hline Caryocha & $0-1$ & $2-33$ \\
\hline Distephanus (quad.) & 50 or 60 & $10-30$ \\
\hline Naviculopsis & $<4$ & $20-40$ \\
\hline
\end{tabular}

The dark greenish-gray diatom coccolith chalk in Core $67 \mathrm{X}$ changes in color to light greenish gray coccolith chalk immediately above in Core $66 \mathrm{X}$ according to the core logs. This supports the between-core break in the sediment record that is indicated by the sharp changes in generic abundances between Floras B and C.

Within Core $66 \mathrm{X}$ a minor change is shown at the species level by several abundance transitions:

1. Most prominently, the predominance among Naviculopsis changes from $N$. lata to $N$. lata var. obliqua upward from Sections $66 \mathrm{X}-5$ through $66 \mathrm{X}-4$.

2. The last significant occurrences of Distephanus quinquangellus is in Section 66X-5.

3. Also diminished at this level are Caryocha sp. and Distephanus schauinslandii.

Core photographs of Sections $66 \mathrm{X}-5$ and $66 \mathrm{X}-4$ show a single uniform lithologic unit. Therefore, Flora $\mathrm{Cl}$ and Flora $\mathrm{C} 2$, below and above this transition are ecostratigraphic units reflecting nonsedimentary changes that favored different species within the same genus. In the case of Naviculopsis lata var. obliqua, the transition apparently became permanent (evolutionary). The record from Japan (Sawamura and Nakajima, 1980) shows $N$. lata var. obliqua achieved dominance over $N$. lata and then survived beyond the extinction of $N$. lata.

\section{COMPARISON OF HOLE 883B FLORA TO OTHER AREAS}

The most similar silicoflagellate flora to that of Hole 883B was reported from the Boso Peninsula in Japan (Flora A1 and A2, Sawamura and Nakajima, 1980). Corbisema flexuosa, C. triacantha triacantha, Distephanus crux scutulatus, D. schauinslandii, Naviculopsis la- 


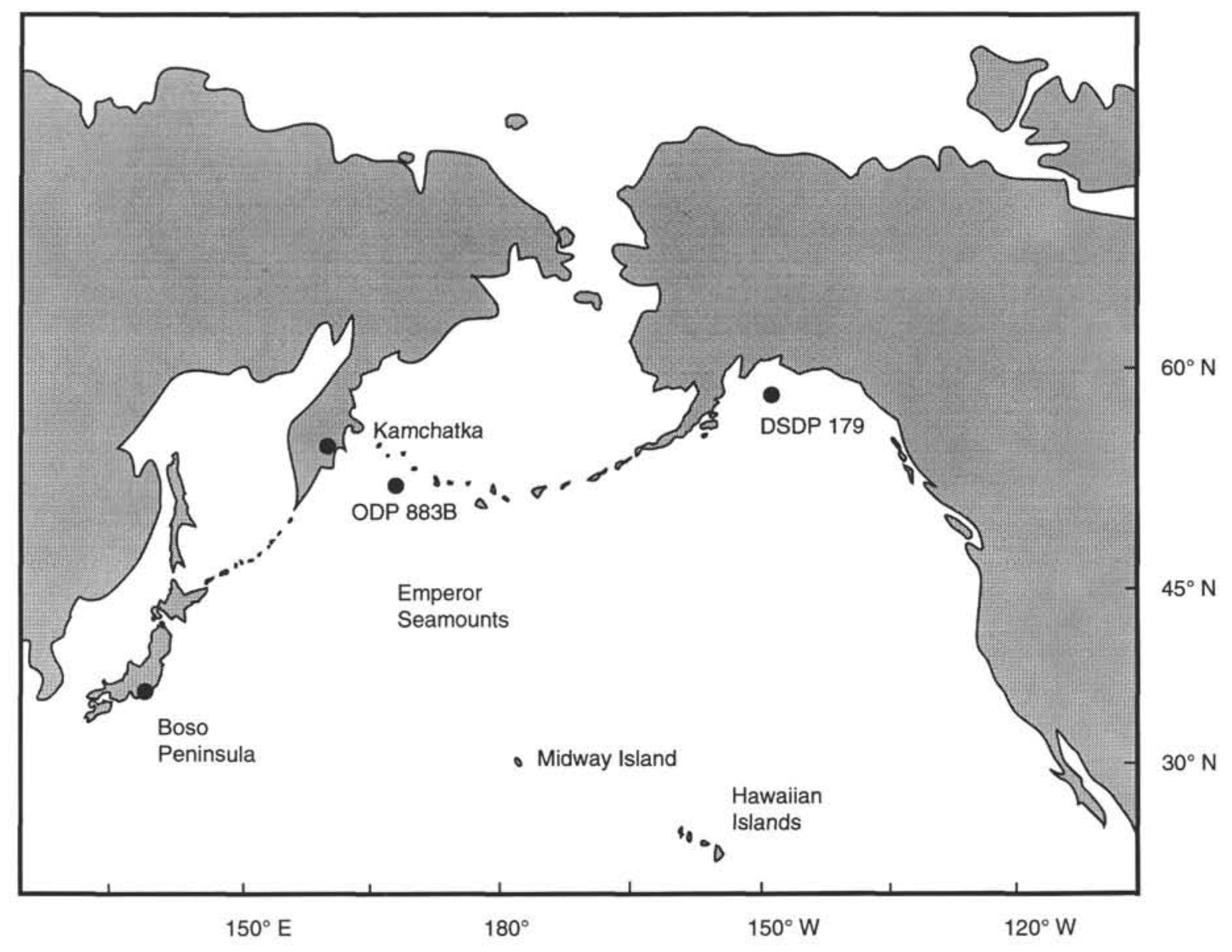

Figure 1. Sketch map of North Pacific region showing locations of reported occurrences of Naviculopsis lata var. obliqua. The Kamchatka occurrence was reported by A. Gladenkov (pers. comm., 1993).

$t a$, and $N$. lata var. obliqua were illustrated from strata assigned to the lowermost Miocene in Japan. This flora resembles that from Core 145-883B-66X, except for the more common occurrence of $C$. triacantha triacantha and the lack of Caryocha sp. The sparseness of $C$. triacantha triacantha at Hole 883B suggests cooler waters than for Japan at that time. The older Naviculopsis biapiculata Zone floras of Cores $67 \mathrm{X}$ and $68 \mathrm{X}$, with prominent $C$. flexuosa, Dictyocha deflandrei, $N$. biapiculata, and $N$. constricta are not recorded at the Japanese sections.

Warm-water silicoflagellate floras of the early Miocene $N$. lata Zone at Japan and on the flanks of the Mid-Pacific Rise (Bukry, 1982, 1985) contain species of Corbisema and Dictyocha that are essentially absent at Hole 883B. Also, the cool-water taxa Dictyocha deflandrei and Distephanus raupii are missing in the older $N$. biapiculata Zone of tropical DSDP Hole 575A (Bukry, 1985).

In the Atlantic, warm-water floras of the late Oligocene and early Miocene at DSDP Holes 369A and 667A (Bukry, 1978b, 1989) are distinguished from those at Hole $883 \mathrm{~B}$ by the distinctly more common and persistent occurrence of Corbisema and by the lack of Caryoch $a$ at the former holes.

At cooler high-latitude sites in the South Pacific, coeval floras contain D. deflandrei (four-sided, $95 \%$ to $99 \%$ ), D. raupii, and Naviculopsis trispinosa in the uppermost Oligocene (Bukry, 1975). Of these, only $D$. deflandrei (five-sided, $98 \%$ ) occurs at Hole 883B. The late Oligocene $N$. biapiculata Zone at ODP Hole 774A in the Southern Ocean has a cool-water flora with taxa that are missing from the North Pacific, such as Dictyocha fischeri, Distephanus crux darwinii, and D. raupii (Bukry, 1991).
Therefore, the $N$. biapiculata Zone at Hole $883 \mathrm{~B}$ can be correlated by cosmopolitan taxa such as $C$. flexuosa, D. schauinslandii, $D$. speculum haliomma, and $N$. biapiculata and more restricted taxa like D. deflandrei. The low frequency of Corbisema indicates that this is not a warm-water flora. For the early Miocene $N$. lata Zone, the transition of $N$. lata to $N$. lata var. obliqua appears to be a regional characteristic in the North Pacific; again, the paucity of Corbisema and the prominence of Caryocha indicates a cooler-water regime than what existed to the south in the region of Japan.

\section{OLIGOCENE/MIOCENE BOUNDARY CORRELATION AND AGE}

The Oligocene/Miocene boundary is traditionally drawn at the base of the Aquitanian Stage in Europe (Ewing et al., 1969). Many fossil groups have provided one or more species events to approximate this boundary away from the type area. For silicoflagellates the first Naviculopsis lata has been widely used. Numerous coccolith events indicated near the boundary include the following $\left(^{\dagger}=\right.$ extinction, ${ }^{*}=$ appearance): Dictyococcites bisectus, ${ }^{\dagger}$ Discoaster druggii, Helicosphaera carteri, ${ }^{\prime}$ H. recta, ${ }^{\dagger}$ Sphenolithus capricornutus, ${ }^{\dagger}$ S. ciperoensis, ${ }^{\dagger} S$. delphix, ${ }^{\dagger}$ Triquetrorhabdulus carinatus, ${ }^{\dagger}$ and Zygrhablithus bijugatus (Bukry, 1978a; Gartner, 1992). A comparable list of silicoflagellate coeval events would include $C$. flexuosa, ${ }^{\dagger} D$. deflandrei, ${ }^{\dagger}$ N. biapiculata, ${ }^{\dagger}$ N. constricta,${ }^{\dagger}$ and $N$. lata ${ }^{*}$ (Martini and Müller, 1976; Bukry, 1981). New studies (Gartner, 1992; Wei and Peleo-Alampay, 1993; S. Cande and D.V. Kent, unpubl. data) have 
Table 1. Occurrence of silicoflagellates in samples from Hole 883B, shown as percentages.

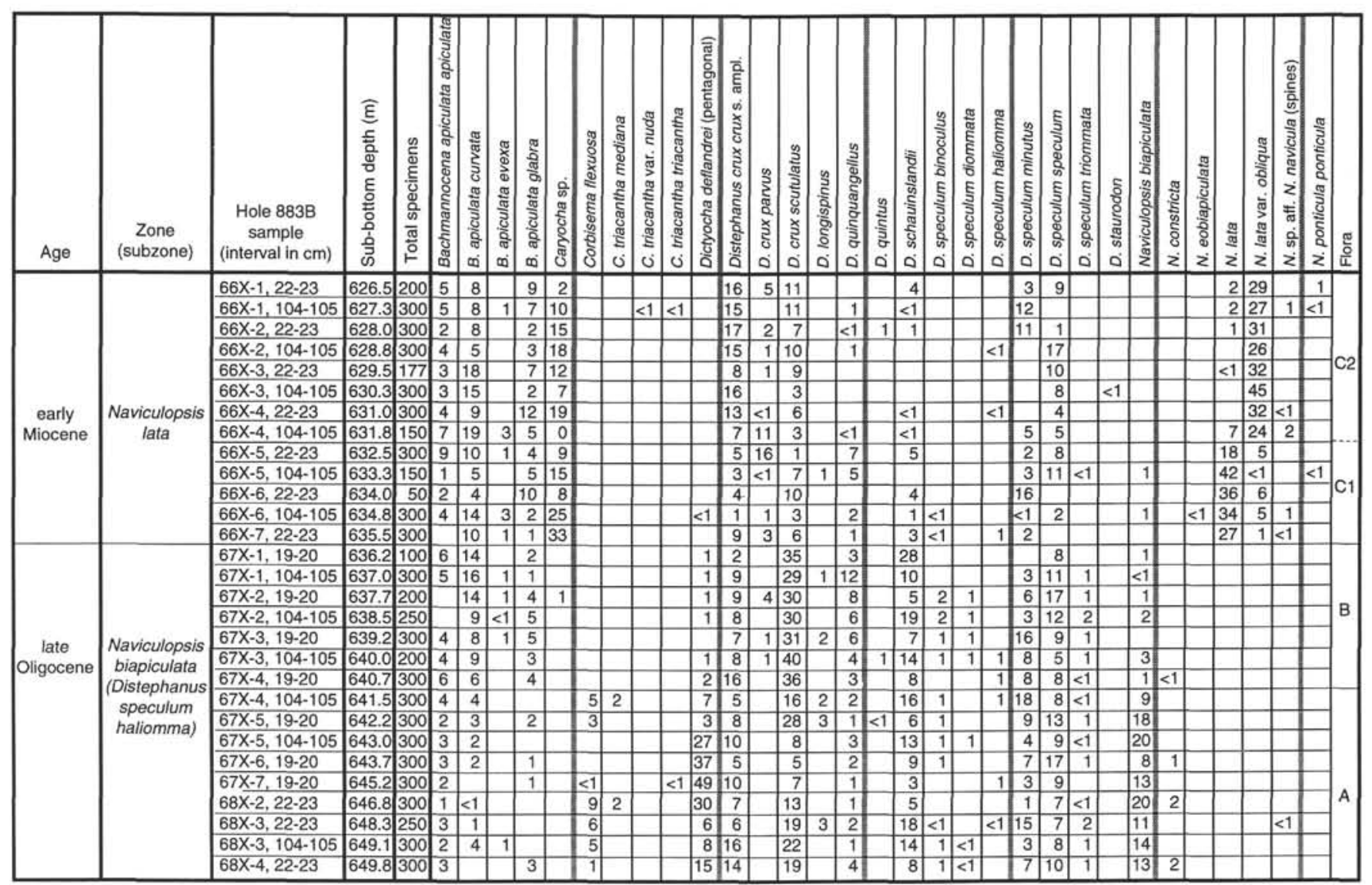

focused on using paleomagnetic Chron $\mathrm{C} 6 \mathrm{CN} .2 \mathrm{n}$ as a cosmopolitan boundary with an age of about 23.7 to $23.8 \mathrm{Ma}$.

Cross-correlation of coccolith and silicoflagellate ranges has indicated that much of early Miocene Zone CN1 (coccoliths) belongs to the N. lata Zone and most of late Oligocene Subzone CP19b belongs to the $N$. biapiculata Zone/Distephanus speculum haliomma Subzone (Bukry, 1981; von Salis, 1993). Note that the late Oligocene age of the upper $N$. biapiculata Zone at Hole $883 \mathrm{~B}$ is in conflict with diatom results that date Core 145-883B-68X at about $20.1 \mathrm{Ma}$, well above the Oligocene/Miocene boundary (J.A. Barron, pers. comm., 1993).

The general best-fit relation of these fossil events to an appropriate paleomagnetic event should be developed. For this report, the $N$. biapiculata Zone is assigned to the Oligocene and the $N$. lata Zone entirely to the early Miocene, especially because of the apparent gap in the silicoflagellate succession at this boundary. The discontinuity in occurrences between Cores $67 \mathrm{X}$ and $66 \mathrm{X}$ of Hole $883 \mathrm{~B}$ suggests missing section in the lower part of the $N$. lata Zone.

\section{CONCLUSION}

Silicoflagellates are common to abundant and moderately well preserved near the Oligocene/Miocene boundary interval of Hole 883B on Detroit Seamount. Distinct shifts in silicoflagellate abundances at the $N$. biapiculatal $N$. lata zonal boundary suggest that the actual Oligocene/Miocene boundary section is missing here. The abundant occurrence of the Oligocene guide species Dictyocha deflandrei in Core 145-883B-68X conflicts with early Miocene diatom correlations.
The presence of $N$. lata var. obliqua in Core 145-883B-66X indicates the upper part of the $N$. lata Zone and correlates to Japanese floras at the Boso Peninsula. The high abundance of $N$. lata var. obliqua at Hole 883B and its absence in coeval beds in the South Pacific and Southern Oceans suggest that it may be an endemic early Miocene guide taxon for the northern Pacific floras.

\section{NOMENCLATURE CITED}

\section{Silicoflagellates}

Bachmannocena apiculata apiculata (Schulz, 1928) Bukry, 1987

B. apiculata curvata (Bukry, 1976) Bukry, 1987

B. apiculata evexa (Bukry, 1984) Bukry, 1987

B. apiculata glabra (Schulz, 1928) Bukry, 1987

Caryocha sp. Bukry and Monechi, 1985

Corbisema flexuosa (Stradner, 1961) Bukry, 1975

C. triacantha mediana Bukry, 1978

C. triacantha var. nuda Bukry, 1982

C. triacantha triacantha (Ehrenberg, 1844) Hanna, 1931

Dictyocha deflandrei Frenguelli, 1940 ex Glezer, 1966

D. fischeri Bukry, 1976

Distephanus crux crux (Ehrenberg, 1840) Haeckle, 1887

D. crux darwinii Bukry, 1976

D. crux parvus (Bachmann in Ichikawa et al., 1967) Bukry, 1982

D. crux scutulatus Bukry, 1982

D. longispinus (Schulz, 1928) Bukry and Foster, 1973

D. quinquangellus Bukry and Foster, 1973

D. quintus (Bukry and Foster, 1973) Bukry, 1981

D. raupii Bukry, 1976

D. schauinslandii Lemmermann, 1901

D. speculum binoculus (Ehrenberg, 1844) Bukry, 1975 
Table 2. Summations of generic percents showing main shifts in silicoflagellate abundances at Hole 883B.

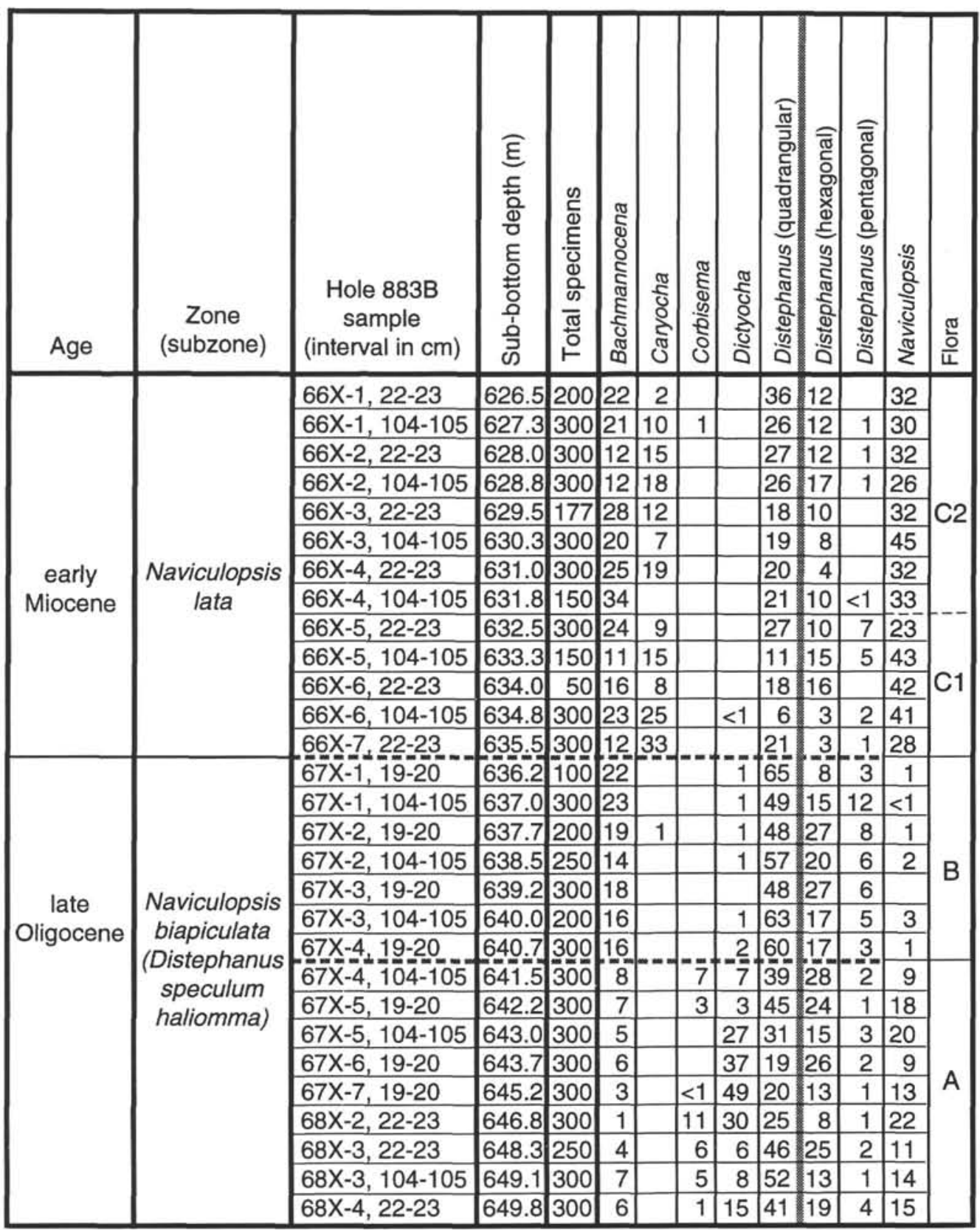

Notes: Main changes are in Section $67 \mathrm{X}-4$ and between Cores $66 \mathrm{X}$ and $67 \mathrm{X}$. The species shifts in Sections $66 \mathrm{X}-4$ and $66 \mathrm{X}-5$ (see Table 1) are not reflected in generic data. Abundance Floras $\mathrm{A}$ to $\mathrm{C} 2$ are shown.

D. speculum diommata (Ehrenberg, 1845) Bukry, 1979

D. speculum haliomma (Ehrenberg, 1844) Bukry, 1978

D. speculum minutus (Bachmann in Ichikawa et al., 1967) Bukry, 1976, emend. Bukry, 1981

D. speculum speculum (Ehrenberg, 1839) Glezer, 1966

D. speculum triommata (Ehrenberg, 1845) Bukry, 1981

D. staurodon (Ehrenberg, 1844) Bukry, 1978

Naviculopsis biapiculata (Lemmermann, 1901) Frenguelli, 1940

N. constricta (Schulz, 1928) Frenguelli, 1940, emend. Bukry in Barron, Bukry, and Poore, 1984

N. eobiapiculata Bukry, 1978

N. lata (Deflandre, 1932) Frenguelli, 1940

N. lata var, obliqua Bukry, 1982

N. sp. aff. N. navicula (Ehrenberg, 1840) Deflandre, 1950

N. ponticula ponticula (Ehrenberg, 1844) Bukry, 1976
N. trispinosa (Schulz, 1928) Glezer, 1966

\section{Coccoliths}

Dictyococcites bisectus (Hay, Moher, and Wade, 1966) Bukry and Percival, 1971

Discoaster druggii Bramlette and Wilcoxon, 1967

Helicosphaera carteri (Wallich, 1877) Kamptner, 1954

H. recta $\mathrm{Haq}, 1966$

Sphenolithus capricornutus Bukry and Percival, 1971

S. ciperoensis Bramlette and Wilcoxon, 1967

S. delphix Bukry, 1973

Triquetrorhabdulus carinatus Martini, 1965

Zygrhablithus bijugatus (Deflandre in Deflandre and Fert, 1954) Deflandre, 1959 


\section{ACKNOWLEDGMENTS}

This report was improved by the review comments of J.A. Barron, I.A. Basov, K. McCartney, P.J. Quinterno, and by ODP editorial comments by E. Mazzullo. I thank J.A. Barron for suggesting detailed examination of the Hole 883B silicoflagellates and K. Purcell for assistance with figure and table preparation.

\section{REFERENCES $*$}

Bukry, D., 1975. Silicoflagellate and coccolith stratigraphy, Deep Sea Drilling Project, Leg 29. In Kennett, J.P., Houtz, R.E., et al., Init. Repts. DSDP, 29: Washington (U.S. Govt. Printing Office), 845-872.

, 1978a. Biostratigraphy of Cenozoic marine sediment by calcareous nannofossils. Micropaleontology, 24:44-60.

, 1978b. Cenozoic coccolith and silicoflagellate stratigraphy, offshore northwest Africa, Deep Sea Drilling Project Leg 41. In Lancelot, Y., Seibold, E., et al., Init. Repts. DSDP, 41: Washington (U.S. Govt. Printing Office), 689-707.

, 1981. Synthesis of silicoflagellate stratigraphy for Maestrichtian to Quaternary marine sediments. In Warme, T.E., Douglas, R.C., and Winterer, E.L. (Eds.), The Deep Sea Drilling Project: a Decade of Progress. Spec. Publ.-Soc. Econ. Paleontol. Mineral., 32:433-444.

, 1982. Cenozoic silicoflagellates from offshore Guatemala, Deep Sea Drilling Project Site 495. In Aubouin, J., von Huene, R., et al., Init. Repts. DSDP, 67: Washington (U.S. Govt. Printing Office), 425-445.

1983. Upper Cenozoic silicoflagellates from offshore Ecuador, Deep Sea Drilling Project Site 504. In Cann, J.R., Langseth, M.G., Honnorez, J., Von Herzen, R.P., White, S.M., et al., Init. Repts. DSDP, 69: Washington (U.S. Govt. Printing Office), 321-342.

1985. Tropical Pacific silicoflagellate zonation and paleotemperature trends of the late Cenozoic. In Mayer, L., Theyer, F., Thomas, E., et al., Init. Repts. DSDP, 85: Washington (U.S. Govt. Printing Office), $477-$ 497.

1989. Tropical Atlantic silicoflagellates from Leg 108 cores off Africa. In Ruddiman, W., Sarnthein, M., et al., Proc. ODP, Sci. Results, 108: College Station, TX (Ocean Drilling Program), 487-489.

1991. Oligocene and Quaternary silicoflagellates from the Kerguelen Plateau. In Barron, J., Larsen, B., et al., Proc. ODP, Sci. Results, 119: College Station, TX (Ocean Drilling Program), 933-934.

Ewing, M., Worzel, J.L., Beall, A.O., Berggren, W.A., Bukry, D., Burk, C.A., Fischer, A.G., and Pessagno, E.A., Jr., 1969. Time stratigraphic framework. In Ewing, M., Worzel, J.L., et al., Init. Repts. DSDP, 1: Washington (U.S. Govt. Printing Office), 643-651.

Gartner, S., 1992. Miocene nannofossil chronology in the North Atlantic, DSDP Site 608. Mar. Micropaleontol., 18:307-331.

Martini, E., and Müller, C., 1976. Eocene to Pleistocene silicoflagellates from the Norwegian-Greenland Sea (DSDP Leg 38). In Talwani, M., Udintsev, G., et al., Init. Repts. DSDP, 38: Washington (U.S. Govt. Printing Office), 857-895.

Sawamura, K., and Nakajima, T., 1980. Miocene silicoflagellate zones in the Boso Peninsula. Chishitsu Chosasho Geppo [Bull. Geol. Surv. Jpn.], 31:333-345.

von Salis, K., 1993. First Oligocene silicoflagellates from N. Europe (Silstrup, Denmark). Zitteliana, 20:79-86.

Wei, W., and Peleo-Alampay, A., 1993. Updated Cenozoic nannofossil magnetobiochronology. INA. Newsl., 15:15-21.

Date of initial receipt: 30 March 1994

Date of acceptance: 23 June 1994

Ms 145SR-143 